\title{
Effectivenes of Mentoring Program to Improving Attitude of Pasien Safety
}

\author{
Andaliaroza $^{1}$, and Putri Wulandini ${ }^{2}$ \\ Lecturer $^{1,2}$, Diploma 3 Nursing Department ${ }^{1,2}$ \\ Faculty of Medicine and Health Sciences, Abdurrab University ${ }^{1,2}$ \\ Jl.Riau Ujung No.73, Pekanbaru, Riau ${ }^{1,2}$
}

\begin{abstract}
The occurrence of a patient safety incident in a hospital will have an adverse impact on the hospital, staff, and patients as service recipients. The impact caused is a decrease in the level of public trust in health services. . Efforts to implement a patient safety culture can be various and mentoring is a more appropriate way. This is because mentoring can provide support to individuals in the learning process with more powerful strength. This study uses a quasy experimental research type. This design consists of two groups, namely the experimental group and the control group. The research sample in this study were student nurses who would practice nursing clinics. The sampling technique used was random sampling. The research instrument used for this study was a pre-test and post-test questionnaire about patient safety knowledge along with a mentoring program to increase patient safety knowledge. data processing includes editing, coding, processing, cleaning, and tabulating. Data analysis includes: validity \& reliability test, univariate analysis and bivariate analysis using SPSS assistance. The results of the study obtained there was a change in attitude in the experimental group with p-value 0.000 ; There was a change in attitude in the control group and the experimental group on the post test with a $p$ value of 0.00 . It is hoped that educational institutions will find out how prepared students are to enter the hospital regarding Patient Safety.
\end{abstract}

Keywords:- Pasien Safety, Metoring Program.

\section{INTRODUCTION}

Patient safety incident data in Indonesia published by KKPRS (Hospital Patient Safety Committee) contained 114 patient safety incident reports in 2009, 103 reports in 2010, and 34 reports in 2011 in the first quarter ((KKPRS) 2012). The occurrence of a patient safety incident in a hospital will have an adverse impact on the hospital, staff, and patients as service recipients. The impact is a decrease in the level of public trust in health services (Rosyada 2014).

Efforts to implement a patient safety culture can be various and mentoring is a more appropriate way. This is because mentoring can provide support to individuals in the learning process with more powerful strength. Individuals will feel more comfortable if they have a mentor who can help them at any time (Nurmalia 2013). The mentoring process applies a learning model according to the level of the mentee's needs so that the process of internalizing something will be easier (Dadge, Jean, \& Casey 2009).

Mentoring has been proven to be effective in improving the perceptions and skills of nurses which will later influence the behavior of the nurses. The mentoring process applies a learning model according to the level of the mentee's needs so that the process of internalizing something will be easier to obtain (Dadge, Jean, \& Casey 2009). Qualitative research (action research) conducted by (Norwood 2010) found that mentoring was proven to be effective in increasing nurses' perceptions of their work, increasing knowledge and skills so that it had an impact on communication and conflict resolution. The mentoring program conducted by Stacy Cottingham for 18 months shows that $100 \%$ of program participants are satisfied and $100 \%$ of participants also say that they will continue to work in their respective institutions. Mentoring also reduces hospital costs by $24 \%$ due to nurse turnover (Cottingham, S., DiBartolo 2010). Mentoring is a learning process in which the mentor is able to make mentees (mentoring participants) who were dependent become independent. Mentoring is a hidden "off-line help" from mentor to mentee for the transfer of knowledge, thinking at work significantly (Nurmalia 2013).

Attitudes are all actions and actions based on the position and belief they have. Attitude is an evaluative statement of everything, it can be an object, person or event. Attitude reflects a person's feelings for something.

In the hospital, not only are nurses who are in charge of caring for patients but there are also prospective nurses who are in charge of caring for patients, one of which is a Nursing Student. These nursing students consist of students taking diploma, undergraduate and postgraduate programs. In the Diploma 3 program of student nursing, almost $40 \%$ of the curriculum is in practical fields, one of which is a hospital. So it should be very necessary to carry out a mentoring program to increase attitudes to students who want to practice service in the hospital, so that unexpected incidents can be suppressed.

This research will be conducted on nursing students at Abdurrab University, Abdurrab University campus is located on Jalan Riau Ujung No. 73 Pekanbaru City. Department of Nursing D III Abdurrab University is the first nursing school in Riau province, which in 2020 has a total of 96 student nurse candidates. Nursing at Abdurrab University, made the Arifin Achmad Regional Hospital in 
Riau Province, the Tampan Hospital of Riau Province, the Puskesmas Puskesmas in Pekanbaru City and the Tresna Werdha Nursing Home as practice places for students.

Based on the results of interviews conducted with $5 \mathrm{D}$ III Nursing students at Abdurrab University, 3 of them did not have a good attitude towards patient safety. Based on the preliminary study above, the researchers are interested in conducting research on the Effectiveness of the Mentoring Program on Improving Patient Safety Attitudes in D III Nursing Students at Abdurrab University Before Hospital Clinical Practice in 2020.

The purpose of this study was to determine the effectiveness of the mentoring program in improving patient safety attitudes in D III Nursing Students of Abdurrab University before Nursing Clinical Practice at the Hospital.

\section{LITERATURE REVIEW}

Patient safety is a basic principle of health care (WHO). Patient safety according to Sunaryo (2009) is that there are no errors or freedom from injury due to accidents. Hospital patient safety is a system where the hospital makes patient care safer which includes risk assessment, identification and management of matters related to patient risk reporting and incident analysis. Ability to learn from incidents and follow-up and implement solutions to minimize risks and prevent injuries caused by mistakes resulting from taking an action or not taking the action that should be taken (RI 2014).

Attitude According to Zimbardo and Ebbesen, attitude is a predisposition (a state of being easily influenced) to a person, idea or object which contains cognitive, affective and behavioral components (in Linggasari, 2008). There are three components of attitude, with respect to work environment factors, as follows: 1) Affection which is an emotional component or feeling. 2) Cognition is a person's evaluative belief. Evaluative beliefs, manifested in the form of impressions or good or bad impressions a person has of a particular object or person.

Mentoring comes from Greek mythology, the word mentor means to act as an adviser, role model, counselor, tutor and / or teacher (Nurmalia 2013). Mentoring is a learning process in which the mentor is able to make mentees (mentoring participants) who were dependent become independent. Mentoring is a hidden "offline help" from mentors to mentees for the transfer of knowledge, thinking in a significant way (Norwood 2010). Mentoring is also a relationship between two people that provides opportunities for discussion that results in reflection, carries out activities / assignments and learning for both of them based on support, constructive criticism, openness, trust, appreciation and a desire to learn and share (Anderson 2011).
Mentoring is a form of support, constructive feedback for mentees in improving their abilities. Mentoring is a mutually beneficial relationship from someone who has more experience to less experienced individuals to identify and achieve common goals (Anderson 2011). Mentoring is a learning process where helping, personal and reciprocal relationships are built with a focus on achievement and emotional support (Nurmalia 2013).

\section{METHODE}

This study used a quasy experimental research type with a non-equivalent design. This design consists of two groups, namely the experimental group and the control group. Then the pre-test was carried out in the two groups, and followed by the intervention in the experimental group. After the mentoring was carried out four times, then a post used was random sampling with a total sample of 30 respondents (15 control groups and 15 experimental groups).

The research instrument used for this study was a pretest and post-test questionnaire about patient safety knowledge along with a mentoring program to improve patient safety culture.

Data processing is part of a series of activities carried out after data collection. For convenience in data processing, a computer program is used. Data processing steps include editing, coding, processing, cleaning, and tabulating. Data analysis was carried out in stages which included validityand reliability tests, univariate and bivariate analysis.

\section{ANALYSIS}

\begin{tabular}{|c|c|c|c|}
\hline No & $\begin{array}{l}\text { Variable and } \\
\text { Cathegory }\end{array}$ & Frequency & Percentace \\
\hline \multirow[t]{4}{*}{1} & Gender & & \\
\hline & Man & 0 & 0 \\
\hline & Woman & 15 & 100 \\
\hline & Total & 15 & 100 \\
\hline \multirow[t]{4}{*}{2} & Source of information & & \\
\hline & $-\quad$ ever & 15 & 100 \\
\hline & never & 0 & 0 \\
\hline & Total & 15 & 100 \\
\hline \multirow[t]{5}{*}{3} & Source of information & & \\
\hline & - $\quad$ Book & 3 & 20 \\
\hline & Journal & 1 & 6.67 \\
\hline & - $\quad$ Internet & 11 & 73.33 \\
\hline & Total & 15 & 100 \\
\hline \multirow[t]{4}{*}{4} & Attitude Pre & & \\
\hline & - $\quad$ Good & 7 & 46.7 \\
\hline & - $\quad$ Not good & 8 & 53.3 \\
\hline & Total & 15 & 100 \\
\hline \multirow[t]{4}{*}{5} & Attitude Post & & \\
\hline & - $\quad$ Good & 7 & 46.7 \\
\hline & $-\quad$ Not good & 8 & 53.3 \\
\hline & Total & 15 & 100 \\
\hline
\end{tabular}




\begin{tabular}{|c|c|c|c|}
\hline No & $\begin{array}{c}\text { Variable and } \\
\text { Cathegory }\end{array}$ & Frequency & Percentace \\
\hline \multirow[t]{4}{*}{1} & Gender & & \\
\hline & Man & 3 & 20 \\
\hline & Woman & 12 & 80 \\
\hline & Total & 15 & 100 \\
\hline \multirow[t]{4}{*}{2} & Source of information & & \\
\hline & - $\quad$ ever & 15 & 100 \\
\hline & never & 0 & 0 \\
\hline & Total & 15 & 100 \\
\hline \multirow[t]{5}{*}{3} & Source of information & & \\
\hline & $-\quad$ Book & 3 & 20 \\
\hline & Journal & 0 & 0 \\
\hline & - $\quad$ Internet & 12 & 80 \\
\hline & Total & 15 & 100 \\
\hline \multirow[t]{4}{*}{4} & Attitude Pre & & \\
\hline & - $\quad$ Good & 7 & 46.7 \\
\hline & $-\quad$ Not good & 8 & 53.3 \\
\hline & Total & 15 & 100 \\
\hline \multirow[t]{4}{*}{5} & Attitude Post & & \\
\hline & - $\quad$ Good & 13 & 86.7 \\
\hline & $-\quad$ Not good & 2 & 13.3 \\
\hline & Total & 15 & 100 \\
\hline
\end{tabular}

Table 2:- Univariate Data Frequency Distribution of Experimental Group

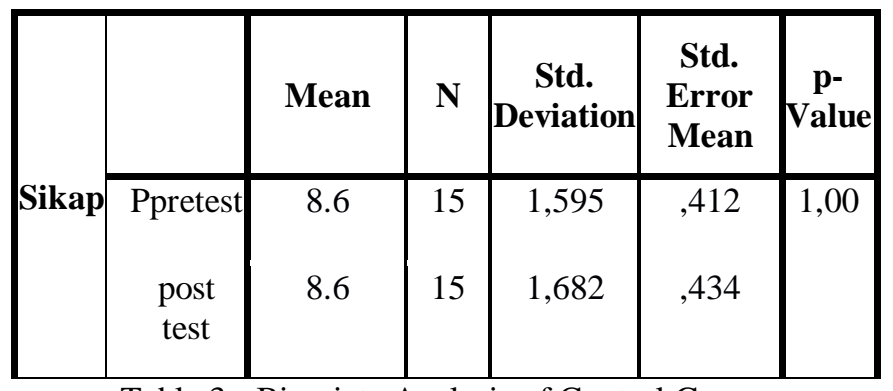

Table 3:- Bivariate Analysis of Control Group

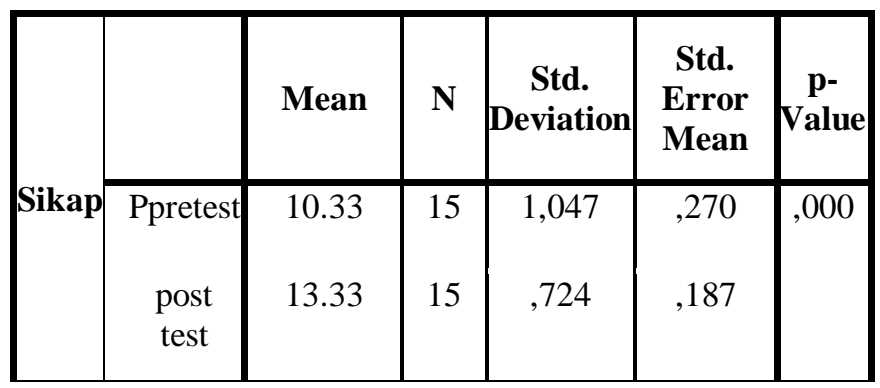

Table 4:- Bivariate Analysis of Experimental Group

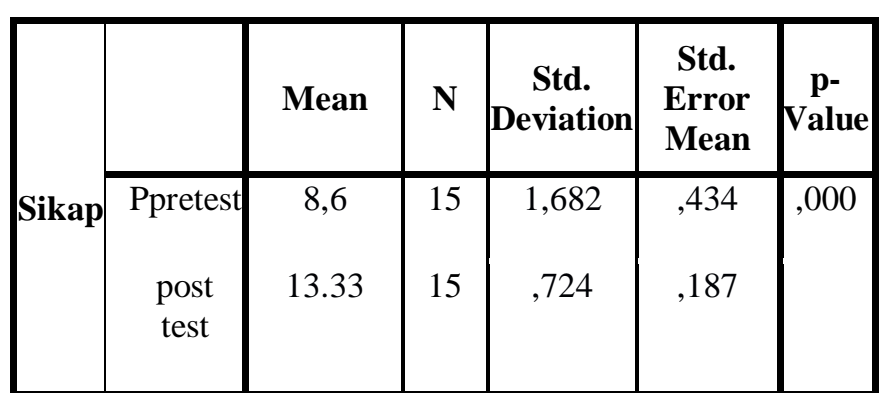

Table 5:- Post Control \& Post Experiment Bivariate Analysis

\section{DISCUSSION}

\section{Changes in attitudes in the experimental group}

From the results of the dependent T-test showed the average difference in the results of the experimental group's attitude before and after being given the mentoring program treatment to students. It can be seen that the average attitude result before being given therapy is 10.33 and after being given a mentoring program it is 13.37 . There is an average difference after the mentoring program is carried out with a value of $p=0.000$ with a value of $\alpha=0.05$ which means that the p-value is $0.0000<0.05$, so it can be concluded that Ha failed to be rejected. The results of this study indicate that the provision of mentoring programs has a significant effect on improving attitudes. When given a mentoring program for four times to respondents / some respondents said this program adds insight and knowledge about patient safety which will have an impact on changing student attitudes.

In the control group there is no average difference in attitudes in the control group before and after without being given treatment. It can be seen that the average attitude before 8.6 and after 8.6. The mean for both is the same, the $p$ value is obtained $=1,000$, so it can be concluded that Ho failed to be rejected.

According to the researcher's assumption, there was a change in attitude in the experimental group because the experimental group received treatment in the form of mentoring activities, while in the control group there was no change in attitude because the control group did not receive treatment in the form of mentoring activities.

The process of forming attitudes takes place gradually and through the learning process. This learning process can occur due to personal experiences with certain objects (people, objects or events) by connecting the object with other experiences or through a combination of these ways. The process of forming attitudes is the influence of other people, especially their peers. The ability to think, the ability to choose and other intrinsic factors affect a person's attitude towards objects, other people, and towards events. Attitudes can change from positive to negative and vice versa, no one is always consistently right continuously, or it is not impossible that there is inconsistency in one's attitude towards certain objects, events and people. A positive attitude tends to action is to approach, enjoy expecting a certain object, while a negative attitude has a tendency to avoid, avoid, hate, dislike certain objects. Because mentoring is a relationship between two people that provides opportunities for discussion that results in reflection, carries out activities / assignments and learning for both based on support, constructive criticism, openness, trust, appreciation and a desire to learn and share (Anderson 2011). Which later will form a positive attitude.

This study is in line with research by Ade Hidayat (2013) on the effectiveness of mentoring programs in improving student intelligence and research conducted by Devi Nurmalia on the Effect of Mentoring Programs on Improving Patient Safety Culture. 
2. Changes in attitudes in the control and experimental groups on the post test results

From the results of the dependent T-test shows the average difference in the results of the attitude of the control group after no treatment and the experimental group after being given the mentoring program treatment to students. It can be seen that the mean result of the attitude of the control group after no therapy was 8.60 and the experimental group after being given the mentoring program was 13.33 . There is an average difference between the control group and the experimental group with a value of $\mathrm{p}=0.000$ with a value of $\alpha=0.05$, which means that the $p$-value is $0.0000<0.05$, so it can be concluded that $\mathrm{Ha}$ failed to be rejected. The results of this study indicate that the provision of mentoring programs has a significant effect on improving attitudes.

According to the researchers' assumptions, mentoring activities can affect the occurrence of changes in attitudes, this can be seen in the results of statistical data between the results of the post test of the two groups of respondents, in the experimental group there was a change in attitude due to treatment in the form of mentoring activities carried out for four meetings.

Nurses have different and specific needs for learning. Mentoring helps meet the learning needs of nurses. Nurses can use mentoring as a counseling process, role models and friendship. Nurses can share experiences, ideas from experienced nurses to those with less experience (counseling). After the transfer of knowledge and experience occurs, a positive attitude will be created from the nurses (Norwood, 2010).

\section{CONCLUSSION}

a. There was a change in attitude in the experimental group with a p-value of 0,000

b. There was a change in attitude in the control group and the experimental group on the post test with a $p$ value of 0.00

\section{REFERENCES}

[1]. (KKPRS), Komite Keselamatan Pasien Rumah Sakit. 2010. Pedoman Pelaporan Insiden Keselamatan Pasien (IKP). Jakarta: KKPRS.

2012. "Laporan IKP Triwulan I Tahun 2011."

[2]. Anderson, L. 2011. "A Learning Resource for Developing Effective Mentorship in Practice." Journal Of Nursing Standard 25(51).

[3]. Cottingham, S., DiBartolo, M. C. 2010. "Partners in Nursing: A Mentoring Initiative to Enhance Nurse Retention." Nursing Education Research 32(4).

[4]. Dadge, Jean.,\& Casey, D. 2009. "Supporting Mentors in Clinical Practice." Journal Nursing Children and Young People 21(10).

[5]. Febrianita, Yulia. 2016. "Hubungan Peran Champion Keselamatan Pasien Dengan Penerapan Budaya Keselamatan Pasien Pada Perawat Di Ruangan Rawat Inap RS X." Universitas Andalas.
[6]. Fleming, M., \& Wentzell, N. 2008. "Patient Safety Culture Improvement Tool: Development and Guidelines for Use. Healthcare Quarterly, 11, 10-15. doi:10.12927/hcq.2013.19604."

[7]. Gangliardi, A, R.dkk. 2009. "Exploring Mentorship as a Strategy to Build Capacity for Knowledge Translation Research and Practice: Protocol a Qualitative Study." BioMed Central 4(55).

[8]. Institute, Planning Australia. 2011. "Mentoring Program Guidelines for Mantees and Mentors."

[9]. Marquis, B, L \& Huston, C, J. 2012. Leadership Roles \& Management Function: Theory \& Aplication. Seven. Philadelphia: Lippincott Williams \& Wilkins.

[10]. Norwood, A. W. 2010. "The Lived Experience of Nurse Mentors: Mentoring Nurses in the Proffesion." University of Missouri-Columbia.

[11]. Notoatmodjo, Soekidjo. 2011a. Ilmu Perilaku Kesehatan. Jakarta: Rineka Cipta. -. 2011b. Metodologi Penelitian Kesehatan. Jakarta: PT. Rineka Cipta.

[12]. Nurmalia, Devi. 2013. "Pengaruh Program Mentoring Terhadap Penerapan Budaya Keselamatan Pasien." Jurnal Manajemen Keperawatan Persatuan Perawat Nasional Indonesia 1(2).

[13]. RI, Departemen Kesehatan. 2014. Panduan Nasional Keselamatan Pasien Rumah Sakit Utamakan Keselamatan Pasien. Jakarta: Depkes.

[14]. Rosyada, Sabila Diena. 2014. "Gambaran Budaya Keselamatan Pasien Pada Perawat Di Unit Rawat Inap Kelas III RSUD Pasar Rebo.” 